undertaking to pay special attention to amenity in afforesting the remainder of the plantable ground. The total area of the estate which will be ultimately planted is less than 2,000 acres of the 7,000 acres purchased. It has become evident that afforestation in the Lake District offers considerable difficulties, as a countryside can be completely changed by stretches of woods, and especially coniferous woods. With this object in view, the Joint Committee has recommended that a central block of some three hundred square miles in extent should be excluded from afforestation work.

\section{British Films and the Cinema}

THE Committee appointed by the Board of Trade to consider the position of British films in view of the approaching expiry of the Cinematograph Films Act, 1927, has now issued its report (Cmd. 5320. London : H.M. Stationery Office. 9d. net). It finds that in some important respects the situation is still the same as in 1926, The much greater home market available for United States films, which is represented by some 11,500 picture-houses and a seating capacity of about $10,000,000$, as against 4,300 cinemas in Britain and a seating capacity, including that of the Dominions, of less than $6,000,000$, offers a security encouraging a flow of capital to the American industry which finds no parallel here. The United States accordingly occupies a commanding position, contributing all but 25 per cent of the films shown in Great Britain, and the Committee was unanimous in its decision that the quota system should be continued and the quotas, under certain conditions, increased. The detailed proposals of the report are accordingly designed to deal with admitted flaws in the present system rather than to modify its principles. A quality test is proposed to restrict the deplorable output of bad films made simply to satisfy quota requirements. An increase in the penalty for blind booking, which is to apply to renters and not to exhibitors, removal of restrictions on advance booking but prohibition of block booking, and the application of the quota system to short as well as to long films are among other recommendations of the Committee. It is suggested that long and short films should be judged by different standards, and stress is laid upon the value of the short film as an opportunity of experimenting with new ideas within reasonably safe financial limits. The ultimate aim of the measures proposed is to reach a quota of fifty per cent in the next ten years, and to give effect to its recommendations and administer the provisions of the new legislation required, the report recommends the constitution of a Film Commission of members entirely independent of any professional or financial interest in the industry.

\section{Architectural Lighting}

A PAPER by R. O. Sutherland published in Light and Lighting of December gives a history of the progress made in architectural lighting during the last ten years. He states that this kind of lighting received great inspiration from the French Colonial Exhibition in 1925. As a result of the illumination shown at this festival, ornamental features in the form of tiles and richly decorated panels in moulded glass were popularized in buildings, especially those used for catering and entertainment purposes. The floral character of this lighting soon gave way to a more restrained treatment. Plain sheet opal glazing was largely substituted for moulded glass. This made it economical to have large areas of lighted panels. Once the idea of converting an architectural element into a lighting feature was established, it rapidly became a typical method of architectural lighting technique. A photograph of the lighting of the Egyptian Hall in the London Mansion House, and of the lighting in the library of the University of Cambridge, show how the architectural treatment is emphasized in a simple and dignified way by the illumination. To Londoners and visitors to London the lighting of some of the escalators on the under. ground railways is of interest. The barrel ceiling is lighted from standards placed at 8 -foot intervals, each containing a 100-watt lamp in a suitable reflector. The illumination is ample for the needs of the traveller, and is sufficient for the vault sides to be used as advertisement space. In the lighting of the gallery of the Shakespeare Theatre at Stratfordon-Avon, the acoustic panels at the back of the auditorium are also utilized as light reflectors.

\section{Timber for Wood-Turning}

AN interesting, and, from the point of view of encouraging small local industries in the countryside, practical report has been issued by the Forestry Commission (H.M. Stationery Office, 1936), entitled "On the Demand for Timber in Wood-Turning in Great Britain". The investigation was carried out in 1935 , when 438 firms were visited, all but $14 \cdot 8$ per cent being wood-tumers. The information upon which the report is based comes therefore from 373 firms ranging from single-handed turners who have one room or a small shed fitted up as a workshop, to mass-production factories with a hundred or more automatic or semi-automatic machines. Some of these latter specialize in the production of a single commodity, such as heels for shoes, legs for chairs, bobbins for textile mills, rollers for mangles, the manufacture of tool handles, or bungs for beer-casks ; others are general turners, fabricating a wide variety of products. The majority of the firms are turners only. The last census returned 56,930 persons, including pattern makers (the latter being chiefly of wood), as employed in the United Kingdom in woodturning. It is difficult to obtain figures of the actual consumption of wood in this industry; but, from information supplied, approximately two hundred firms are using 6,000,000 cubic feet of timber in woodturning annually, of which about 53 per cent is homegrown and 47 per cent imported.

\section{Agricultural Meteorology}

Mr. J. W. Hopkins has recently published a paper, entitled "Agricultural Meteorology : Some 
Characteristics of Precipitation in Saskatchewan and Alberta", in which it is apparent that the author's investigations and their results may have a wider application than the merely agricultural (Canadian J. Res., 14, No. 9, Sept. 1936). In previous agricultural meteorological investigations, Mr. Hopkins demonstrated statistically significant correlations between annual variations in rainfall and temperature, and the yield and nitrogen content of wheat crops grown in central and southern Saskatchewan and Alberta. In the present paper, the author gives the results of a study complementary to the previous one, dealing with some average characteristics of the seasonal precipitation in these districts, and also analysing the fluctuations which past experience has shown to occur from year to year in the precipitation at a given place, and from place to place in the same district during a given year. The investigations appear to be based on observations carried on between 1898 and 1934, the stations being Edmonton, Calgary, Battleford and Swift Current. "In spite of irregularities, to be expected in the limited sample of years available," says the author, "the frequency of distribution of seasonal precipitation at the stations showed no gross asymmetry, seasons with precipitation in the vicinity of the average being on the whole more numerous." The average (1916-32) percentage of days on which rain fell showed a distinct seasonal trend during spring and summer, being lowest in April and highest in June. Similar variation was noted in the average amount of rain per rainy day, which was lowest in April and highest in June and July. It would be of interest if in future observations some data could be collected on the subject of the possible influence of the forests on the atmospherical moisture content in these regions.

\section{Plant Pathology in Devon and Cornwall}

The twelfth annual report of the Department of Plant Pathology at the Seale-Hayne Agricultural College, Newton Abbott, Devon, considers the pests and diseases of plants from an essentially local aspect, which should be much appreciated by growers in Devon and Cornwall. Mr. L. N. Staniland, the advisory entomologist, contributes a general section upon the more common pests of farm and garden. $\mathrm{He}$ has made a special study of eelworm troubles. Methods of combating this pest are discussed at considerable length, and a thorough revaluation of the usual hot-water treatment has been made. It has been found that although eelworms are killed by seventeen minutes exposure to a temperature of $110^{\circ} \mathrm{F}$., the technique of commercial treatment varies greatly. The usual period of three hours heating is shown to be inadequate in some cases, and various recommendations as to improved methods are made. $\mathbf{M r}$. A. Beaumont, the advisory mycologist, has made a further detailed study of the relation of potato blight to the weather of Devon, and has separate articles on "Tulip Fire and the Weather", "Snapdragon Rust ; Trials of Resistant Varieties", and "Apple and Pear Fruit-rotting Fungi".

\section{Vital Statistics for England and Wales for 1934}

The text volume of the Registrar-General's Statistical Review of England and Wales for 1934, recently issued, contains the official commentary on the two volumes of vital statistics already published (London: H.M. Stationery Office. 3s. 6d. net). The report deals with the statistics of births, deaths and marriages registered in 1934, estimates of population, and other matters. The estimated population of England and Wales in the middle of 1934 was $40,467,000$ persons, of whom $19,412,000$ were males and $21,055,000$ females. The total is 117,000 , or 0.29 per cent greater than the estimate for the previous year, and 515,000 or $1 \cdot 3$ per cent greater than the population at the census of 1931. The average ages of the estimated population, which are gradually increasing, are 32.4 years for males and $34 \cdot 2$ for females. In addition to reviewing the mortality from various causes, the report also contains several studies of mortality. One of these deals with the handicaps suffered by the winter-born compared with the summer-born child, and another with the mortality rate from pregnancy and child. bearing for the wives of men in various social groups.

\section{Fall in French Birth-Rate}

THE annual number of births in France reached its maximum towards the end of the Second Empire, when it was so high as $1,034,000$ in 1868 . In 1934 it had fallen to 677,000 and in 1935 to about 650,000 , of which nearly 50,000 were the children of foreigners. The birth-rate has therefore diminished by 384,000 or nearly a third, although the population has increased since 1868 by three million immigrants or naturalized persons, which has resulted in increasing the population from 38 to 48 million inhabitants. During the period 1900-35, the birth-rate has decreased by nearly 100,000. The number of births per marriage has decreased even more rapidly. In 1800 the average number of births in France was 4.5 per marriage, at the end of last century it was 3 , and to-day only $2 \cdot 2$, or a diminution of about fifty per cent.

\section{The Value of Experiments on Animals}

ThE autumn issue of the Fight against Disease (24, No. 4), the quarterly journal of the Research Defence Society, contains extracts from the evidence given by Lord Justice Fletcher Moulton before the Royal Commission on Vivisection, 1906-8. The considered opinion of Lord Moulton, whose scientific knowledge and clarity of thought must have materially assisted the Commission in forming an opinion upon the anti-vivisection controversy, should help those who have to address meetings on the question, or have to deal with anti-vivisection propaganda.

\section{Physics in Industry}

AT the meeting at the end of October commemorating the fifth anniversary of the founding of the American Institute of Physics, the replies of fifty leading industrial physicists to the question: what 